\title{
Educational and Socio-Cultural Status of Nepali Women
}

¿ Shanti Bhushal

\section{Abstract}

Education is a factor for enlightening poeple. It is key to empower both men and women and improve their socio-cultural status and quality of life. Therefore, women should have an equal access to education and educational opportunities. But in our context, disparity in education and educational opportunities among men and women exists significantly. Women's educational status is lower than man as indicated by their lower literacy rate. Lower educational status has a number of negative consequences in Nepalese women's life.

[Key words : educational status, socio-cultural status, hindu philosophy, discrimination]

\section{Introduction}

An individual needs a society to spend his/her social life. Interaction of the individual results in the formation of society .In addition to that socio-cultural system is formed by the interaction done by the rule, sub-rule and ideal law. In social system, different efficiency, skill, talents possessing people are included and related to their work and duty. The society hopes a lot from them. An individual has his/her role according to the status. For the knowledge of people's prestige and their position, group and function, the word i.e. status and role are used. Each and every individual living in a society may have high or low thinking capacity. An individual has different roles in different aspects of life. For example, the person having head position in a family has different positions in different fields. Every society has given an individual more than one position. For example ; father , mother , son , daughter , maternal uncle, maternal aunt, daughter in law , lectures ,politician ,lawyer and so on. Based on above position and relation every individual should perform some work in respective fields. If an individual fails to perform his responsibility and duty, it creates an imbalance in the socio cultural system. Hence, according to the status and role, each society plays a cultural work. 


\section{Educational and .... (Bhushal)}

Living in the area of socio-cultural system, an individual in any condition related to his $\backslash$ her social position should play a vital role regarding that system. This balances the real basis of socio - cultural system. In the same way, status and role play a vital role to regulate socio - cultural system. On the level of status and role, society is divided into different groups viz; society, family, sex, age, caste, class, occupation which provide knowledge and skill to an individual. Marriage creates status like husband and wife, sister in law, maternal uncle and aunt, brother in law, father in law, mother in law, and so on. On the basis of family there are status like mother -father, brother -sister, grandmother - grandfather, and grandson granddaughter, etc. An individual has one position in his group or society. It may be high or low. When a woman is declared as prime minister, the status is high whereas a woman becomes daughter in law; the status (position) is low. Similarly, each individual carry out his work according to his position. The role carried out by an individual according to his/her status is known as person role. That's why status and role are considered as two wheels of a cart and two sides of a coin. In absence of one, another is incomplete. An individual can be differentiated by his status or role.

Every individual has one or more role in society and community. According to the famous sociologist Robert Bierstedt, "Society is a network of social status." Likewise according to the Dictionary of Sociology, "Social status is the position by a person, family or kinship in a social system related to others which determine rights, duties and other behavior". Similarly, according to Elliott and Murrill,"Status is the position which the individual occupies in the group by virtue of his sex, age, family, class, occupation, marriage and achievement.” On the basis of above definition, status and role is the representative (indicator) of position and function of individual's community and society. In a society there exist different kinds of behavior. They are determined by different role and status. The technical reciprocal model of that behavior is known as status and role. Ancient primitive or modern society plays a definite status and role for any members. An individual should perform his duty related to his position. Nepalese society has determined traditional position and role for man and woman. A brief 
introduction of how women are provided educational and socio-cultural position related to different aspects is given below:

\section{Educational Status and Role of Nepalese Women}

Education is the main factor through which one can achieve knowledge, awareness and rational. Knowledge is indispensable factor of our life. Knowledge and rationality plays a vital role to run our life smoothly. A country cannot hope for skilled and devoted manpower in absence of education. That's why each family and society should give first priority to provide their children quality education because without education, a society is in darkness and hampers the overall development of the country. Society is prominent for human existence. The society whose root is strong comes out to be rational and structured. With the help of disciplined, conscious and rational human, able and responsible, structured and lawful society is formed. To produce such skilled manpower every individual, family, society and the country should give first importance to education. To judge how much a society, family, and country is capable, we consider education as the main factor. In the same way, families will also determine the status of the country. Hence, education is standard of a country.

Men and women regarded as two sides of same coin should equally participate for the development of a country. Listing in the world as a poor and illiterate country is unfortunate for Nepal. Due to lack of education and awareness among people, superstition and other related problems has been deeply rooted in our country. These problems have been obstacle to produce skilled and able manpower. Hence to make the family, society and country free from these frightening (dangerous) factor, education plays the main role. For acquiring education, an individual, family and citizens should be made aware o infrastructures of a nation in which quality education plays an indispensable role. To raise the status of most of the poor and undeveloped country, power and aspiration plays an important role. Our country has been renowned as a country full of superstition. In educational sector, its condition is miserable. In comparison to men, women's educational status is painful. 


\section{Educational and .... (Bhushal)}

For the overall development of a society and nation, women participation is a must. But unfortunately women of our country mostly spend their time doing household activities and also involving in agricultural fields. Due to which education and knowledge acquirement is difficult. Daughters are referred as product going to other's house and are refused to acquire education. Traditional superstition and patriarchal feudalist rituals have been deeply rooted in which women in compared to men are considered to have low status. Due to lack of quality education, women are denied from rules, regulation and their responsibility. Low educational system has not only limited women skill and capability but also individual health, family health, legal right, constitutional right, its utilization and active participation, etc. are being obstacles. Similarly, women are backward in discriminative policy and educational advantage. Due to lack of education, women cannot afford themselves and need to depend on men for survival. Hence, to overcome such condition and to develop the country, women education is must. Along with education, related educational training should be provided. In the past time, women are made to participate only in children growing activity. This makes them more dependent on other.

Table: 1 Male and Female Literacy Percentage of Different censuses (2009-2058)

\begin{tabular}{|l|r|r|r|}
\hline Year & \multicolumn{1}{|c|}{ Male } & \multicolumn{1}{c|}{ Female } & \multicolumn{1}{c|}{ Total } \\
\hline 2009 & 9.5 & 0.7 & 5.3 \\
\hline 2018 & 16.3 & 1.8 & 8.9 \\
\hline 2028 & 23.6 & 3.9 & 14.0 \\
\hline 2038 & 34 & 12 & 23.3 \\
\hline 2048 & 54.5 & 25 & 39.6 \\
\hline 2058 & 61.1 & 42.5 & 53.7 \\
\hline
\end{tabular}

Source: Population Census, 2058, CBS

On the basis of above information, Nepal's educational position has been stepping forward to further development. Before 2009, population census was not scientific hence they are not counted. Nepal's whole and malefemale's education status was informed after only 2009. According to population census of 2009 to 2011, total literate was 5.3 percent among 
which 9.5 were of male and 0.7 was female. The female literacy percent was neglected as compared to male. According to population census of 2018, literate percent was 8.9 percent of which 16.3 percent was male and 1.8 was female. Through this we come to know the educational status of women was poor. Similarly, the literacy rate of both male and female go on increasing and finally in population census of 2028, total literate was 53.7 percent of which 42.5 were female and 61.1 were male. Still the percent of female was less in comparison to male. This hampers the overall development of the country.

\section{Social-Cultural Status and Roles of Nepalese Women}

In the present time also, Nepalese society is still affected by traditional values, norms, customs and ideal. Hindu religion and philosophy have encouraged patriarchy. Till 2062 B.S., Nepali constitution had declared Nepal as a Hindu kingdom. Hindu religion and culture has been granting male dominated philosophy. But as referred to Vedic period, male and female are given equal importance. At that time, female were revered and worshipped as the boon of Laxmi, Saraswati and Mahakali. The Great Smritikar 'Manu' had said women had double role in Smriti period. In addition to that, there's saying, "Where there's worshipping system of women, there the god gets happy and female get freedom." Similarly, Post Vedic Period is being affected by this validity. Nepalese society is also affected by Post Vedic period of ancient philosophy. In different period, exploitation, domination and discrimination of women are found. For example, we came to know that in Lichhihavi period, social, economic, political rights were given to the ruling class women.

In today's Nepal also, superstitions as well as co-related problems have been deeply rooted in the society. Child marriage, polygamy, widow marriage, etc. still exist though they have been barred legally. Similarly, Sati system, Slavery systems are pre-existing. In addition to that, social, economical, educational, political rights are less for women as compared to that of men. Women were tortured badly. Modern period is still affected from these problems. In 1977 B.S. and 1980 B.S., Chandra Shumsher abolished Sati system and Slavery system respectively. But society was dominated 


\section{Educational and .... (Bhushal)}

by patriarchal value. In today's situation, Sati system is abolished but other systems are still the same as they were before. After the rise of democracy, the kingdom provided social, economical and political right to women but still they were highly influenced by patriarchal values, norms, etc. From these rights, only few women of institution succeeded to get benefit. Still majority women were dominated. In Nepalese society, the proverbs hang on the mouth of the people that determine the situation of women. Some of such proverbs are “The daughter is others' property Let there be son albeit late; the daughter is a two-day' guest; A party of mutton goes at son's birth; But pumpkin at that of daughters'”

Similarly, Kalidas wrote “aabigan sakuntalam” that has been translated by Sambhu Prasad Dhungel as "Daughters are goods to be given to others, Known as the mortgage; I'm very happy today by bidding farewell; Feeling relieved as if just paid loans”. In the same way, the paragraphs included in Bhanubhakta's creation (book) named Badhusickchya are "Women should never laugh, it is only the whore; Even if they aren't whore, they destroy all the household works". According to above proverbs and writings, it is found that Nepalese women lead a dominated, helpless and painful life and are considered in second place in the society. The example that was prevailed in Vedic period Samata kingdom Samaj Smriti period explains “ Father protects (a daughter) in her childhood; Husband protects her at youth; Son looks after her adulthood; Women are never free as they depend on man".

Seeking the preservation of the father in childhood, husband in adult and son in old age, women are completely made to depend on men. In the same way, in Post Vedic period, Hindu religion and philosophy have affected by Nepalese society and in the perspective to social, economical condition, women are found and being played two roles in which they are referred as both god and devil. In the preservation of Nepalese socio-cultural system, female are respected as motherhood. On the other hand, daughters are respected in the form Kanya-Kumari and sisters. Daughters are said to be pure till they remain in their birth time whereas daughter in-laws are tortured and wife are treated as servants in whom they have to worship their husband. This is vividly described by famous sociologist Lynn Bennett. Kumari are 
referred pure but the women involved in children producing work are compared with pollution. Similarly, woman's sexuality and pollution increase with the increase in the age. All these are described by Bennett in her book. In Hindu religion and culture, women are indicated in the form of power and strength.

Women are affected by migration and urbanization which started by acculturation and assimilation. In a way, woman's position in the society in comparison to man is very weak. Nepal is a country full of multi-lingual, multi-caste, multi-cultural and multi-environment. Nepal is a country of four castes, 36 sub-castes and 61 ethnic groups as well as 125 languages community. But regarding binding of women with socio-cultural position is different. In this type of diversity, the process of gaining Hindu socio-culture and philosophy is in high status in Mongol women than in Hindu women. One of the social problem i.e. polyandry is still prevalence in Himalayan region of the geographical diversity. In most of the Himalayan and Hilly region, polyandry is prevailing which ultimately affects the society. Likewise in mid-western and far western deoki system, bandi custom, touchable and untouchable custom etc. are in popularity. In Chepang ethnic group, during delivery time, there's a custom of going to jungle. (Kantipur, 2064/03/09). Similarly, in Terai region due to witch system, women are tortured physically and mentally. In Kathmandu Valley, Kumari custom, in Muslim group i.e. Parda custom (Burkha) and so on has made the condition of women more sympathetic.

Child marriage, polygamy and other similar problems are still common in society. However widow marriage is not accepted easily. Due to which in women, the exploitation is found in extreme. During menstruation and pregnancy women are considered as untouchable but the baby is considered touchable according to perspective of Hindu religion. The work of neglecting the entrance in water taps, wells and temples is still prevailing in our society that results in the low standard of women. Similarly, low standard women have illegal relationship with high-standard men and the child born from them is not offered citizenship which is found in present situation. Due to superstition, belief and norms, women's social, economical, psychological, mental and physical statuses have been disturbed. Exploitation and 


\section{Educational and .... (Bhushal)}

discrimination are the major problems faced by women. For the sake of women, government and non-governmental institution are carrying out works like education, health, awareness program and employment in the wellfacilated and serviced place.

From the above analysis, we come to know how much the Nepalese women are bounded in their rights and duties. How many women have participation in different aspects? What is the perspective of women in the society? What's their efficiency? In the same way, especially the process of participation and acquiring facilities and services, decision-making etc. by the women in the role of an individual, family, community, public and at national level should be studied thoroughly. And also, up to what excess the powers and rights are gained by the women should be necessarily investigated through the real fact. Famous sociologist Lynn Bennett had explained the status of women in the society; whether they are pure or impure in her book "Dangerous wives and sacred sisters: social and symbolic roles of high-caste women in Nepal”. She has included the topic of purity and impurity in her research book. It is said that Kumari period is regarded as pure but the period of reproducing baby is impure. It has been also mentioned that uncultured nature is dangerous.

Similarly, the hidden reality found in the Nepalese society i.e. the Chepangs are regarded untouchable during delivery and are sent to jungle due to superstition. On the hand, patriarchal feudal rituals and structure had said that male dominating concept has been able to reach the height of the mountain. Gambling, drinking wine and prostitution are still prevailed in Nepalese society. Women are made to suffer. In addition to that, people sit in tea shop and public place and talk about the development and progress of women status. In the same way, firstly man involves women in the political affairs and then they throw tear gas on them (women). This is the condition of woman in our country, Nepal. To involve in this great deed, patriarchal concept should be changed. Feminist women are waiting eagerly for drastic change.

\section{Conclusion}

In brief, for a balanced society, all the people should be given status and role individually. An individual should play the role according to the status 
in any situation. This keeps the social culture in balanced condition. Status is important part of socio-cultural system which regulates an individual. Hence, for the production of qualitative and rational manpower, education is must. For the development of a country, the involvement of both men and women should be there. In educational development, nation's perspective should be positive and for raising the status of women, new policies and plans should be implemented. Today's society is still affected by ancient norms, values and ideas. Society is the group of people having various religions and culture and run by patriarchal feudal system which is fact. Traditional way of treating and behaving opposite sex is still prevailed. On the one side, Kanya, daughter, sister, and mother are worshipped whereas on the other hand wife and daughter in law are tortured physically and mentally. Still the activities of discrimination, exploitation and domination are prevailed. Until and unless these activities are removed, a well developed, cultured and civilized society cannot be imagined. For the end of all these activities against women, society and country's positive perspective is indispensable.

\section{References}

Archarya M. and L. Benett (1981). The Status Of Women In Nepal, Vol III Part 9, CEDA, Kathmandu

Bennett Lynn (1983). Dangerous wives and Sacred Sisters Social and Symbolic Roles of High-Caste Women in Nepal, Columbia University, Press New York.

Bhasin Kamala (1993). What Is Patriarchy, Kali for women, New Delhi. Bouwar Simon da. (1949). The Second Sex Translated by Ramesh Sunuwar, Pragati Pustak Sadan, Delhibazar, Kathmandu.

Central Bureau of Statisitics.(2001). Population Census 2001.Kathmandu: HMG.

Chaturvedi Pandit (1996). Manusmriti, Jwala Prakashan, Ranadhir Prakashan, Railway Road, Haridwar, India.

Upadhya Shieeram (2052). Nepal's Social, Economical and Administrative History

Vidya Bhushan and Sachdeva D.R. (2000). An Introduction to Sociology, Kitab Mahal 22-A Sarojini Naidu Marg, Allahabad. 